\title{
Morphology of Ice Crystals Grown from the Vapour at Temperatures between -4 and $-1.5^{\circ} \mathrm{C}$
}

\author{
By Akira Yamashita and Asaharu Asano \\ Department of Earth Science, Osaka Kyoiku University, Tennoji, Osaka 543, Japan \\ (Manuscript received 19 August 1983, in revised form 20 December 1983)
}

\begin{abstract}
Ice crystals grown in a supercooled cloud at temperatures from -4 to $-1.5^{\circ} \mathrm{C}$ in a cloud chamber of the type of unforced air flow have been studied, with the following findings: All of them are plates in shape, which are categorized into a sector plate $(-4.0 \sim$ $\left.-2.5^{\circ} \mathrm{C}\right)$, a fern-shaped plate $\left(-3.0 \sim-2.0^{\circ} \mathrm{C}\right)$ and a plate with a scalloped periphery $\left(-2.0 \sim-1.5^{\circ} \mathrm{C}\right)$, and the rate of growth in the $a$-axis direction increases as the temperature approaches the melting point. The three types of crystals have a multilayered and plate construction in common. The most conspicuous in the layered construction is the plate with a scalloped periphery, which is characterized by the direction of growth of the tip of a branch that is not always parallel to an a-axis, the number of such branch being vast.
\end{abstract}

\section{Introduction}

Since the early experimental work of Nakaya (1954), the habit and feature of monocrystalline ices grown from the vapour have been investigated; and as a result, qualitatively they seem sufficiently represented in the T-S (temperaturesupersaturation) diagram of Nakaya (1954) or Hallett and Mason (1958) or Kobayashi (1961). Rather quantitatively, however, the habit change of them has been studied by Yamashita (1973 and 1974) also through free fall experiments. Meanwhile, the delicate morphology of ice crystals has not always been sufficiently studied experimentally. Accordingly, ice crystals grown in a new type of cloud chamber have been subjected to the present experiment aimed at studying their delicate morphology at temperatures close to the melting point.

\section{Experimental}

\section{a) Apparatus}

A cloud chamber of the type of unforced air flow (Yamashita and Ohno, 1984) was used in the present experiment. By keeping temperature in the laboratory at $20-30^{\circ} \mathrm{C}$ and the thickness of hard frost covering the upper part of the inside wall of the cloud chamber about $2-4 \mathrm{~cm}$, the vertical profile of temperature and a layer of cloud in the chamber were controlled to be between curves A and B in Fig. 1.

\section{b) Ice crystals grown at temperatures higher than $-4^{\circ} \mathrm{C}$}

When the chamber was run continuously for weeks, a vast number of ice crystals came to

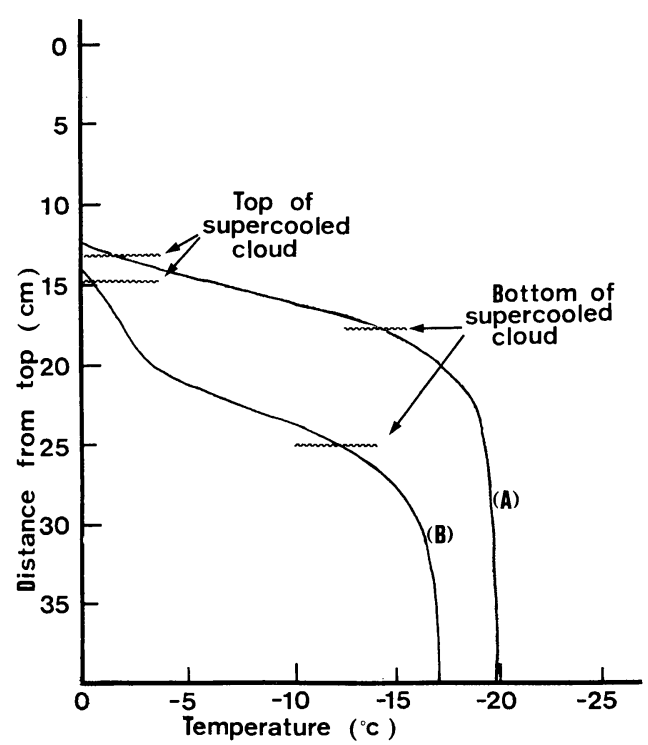

Fig. 1 Temperature profiles. A: hard frost $2 \mathrm{~cm}$ thick; B: $4 \mathrm{~cm}$. 
grow on the surface of hard frost and a vertically suspended thread. Hundreds of those crystals grown at the part of the chamber higher than the level of $-4^{\circ} \mathrm{C}$ were either observed directly or sampled and observed in a cold room. All of them were found plate-shaped, having the number density of about $0.1-1$ per $\mathrm{cm}^{2}$ of hard frost and about 5-20 per $\mathrm{cm}$ of a thread. Meanwhile, when a needle-like crystal grew on the thread at the level of $-5^{\circ} \mathrm{C}$, it was raised to another level of temperature between -4 and $-1.5^{\circ} \mathrm{C}$ by raising the thread upward; then, a large number of plate-shaped crystals came to grow on this initial crystal, as exemplified in Fig. 2. The number density of them varied between 50 and 80 per $\mathrm{cm}$ of a needle when counted under the optical microscope.

Observations under the polarization microscope disclosed that almost all the plates are single crystals having the $c$-axes perpendicular and the $a$-axes parallel to their comparatively flat faces. Morphologically it was possible to classify them roughly into three types. The first type, observed at temperatures between -4.0 and $-2.5^{\circ} \mathrm{C}$ and shown in Fig. 3, has prismatic faces and the same appearances as a sector plate grown at about $-13^{\circ} \mathrm{C}$ in the previous work (Yamashita and Ohno, 1984). The second type, observed at temperatures between -3.0 and $-2.0^{\circ} \mathrm{C}$ and shown in Fig. 4, looks like a fern and has a few groups of many parallel branches, every regularly arranged branch being inferred to have grown at a constant rate. The

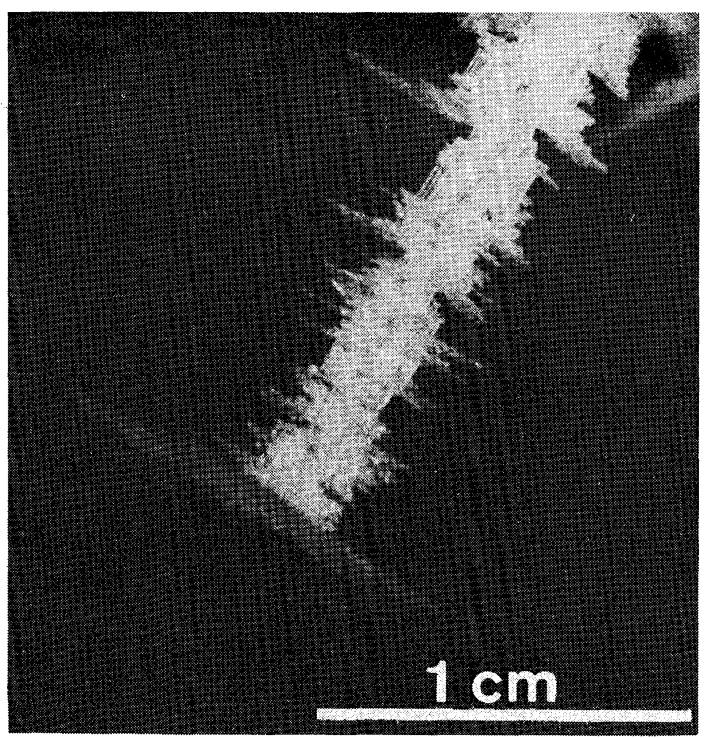

Fig. 2 Plates grown on a needle.

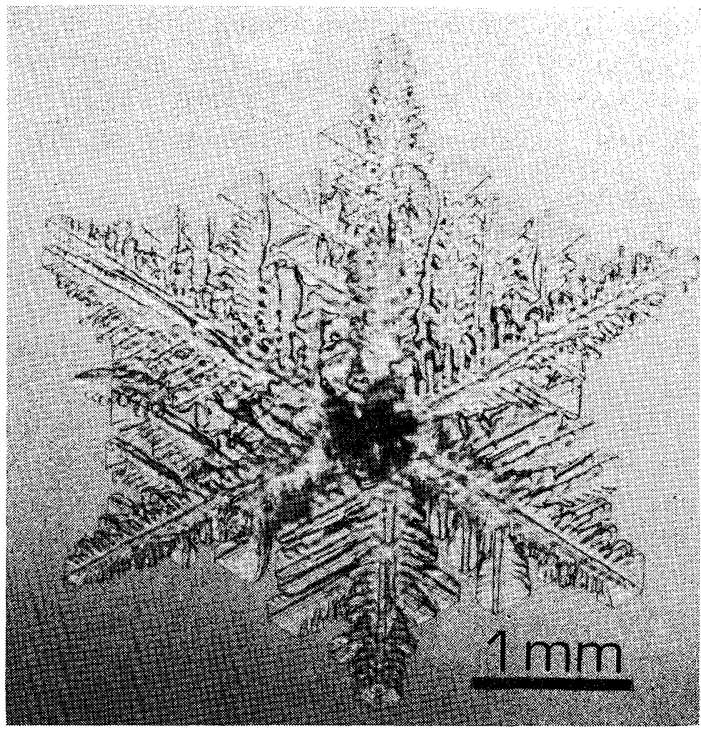

Fig. 3 Sector plate grown at the end of a needle at $-3.8 \sim-3.2^{\circ} \mathrm{C}$.

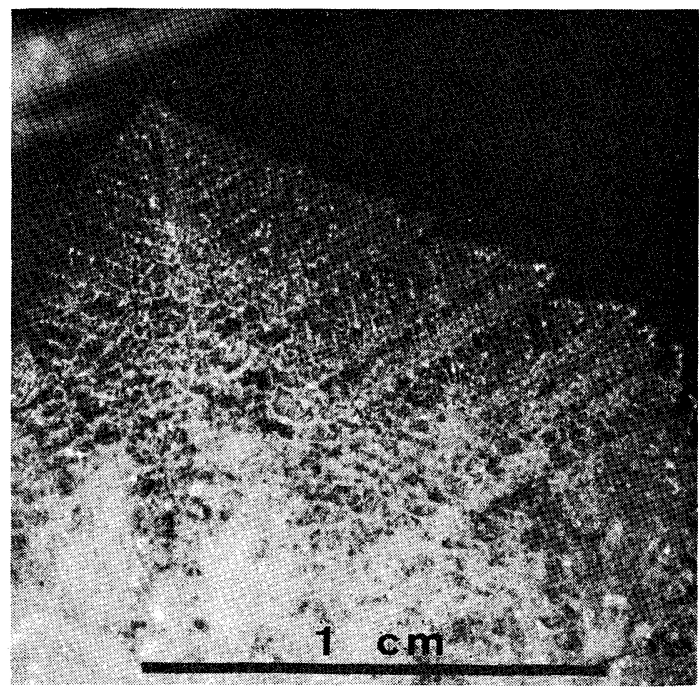

Fig. 4 Fern-shaped plate grown horizontally on hard frost at $-2.5^{\circ} \mathrm{C}$.

third type, observed at temperatures between -2.0 and $-1.5^{\circ} \mathrm{C}$ and shown in Fig. 5, has a scalloped periphery and an appearance resembling a fish scale, as scallops are arranged to form an arc; observations under the optical microscope disclosed no prismatic faces in this type.

The mean value of ratio of growth rate in the direction of $a$-axis to that of the $c$-axis, $a / c$, was about 50. It was almost constant at temperatures between -2 and $-3^{\circ} \mathrm{C}$; between -3 
and $-4^{\circ} \mathrm{C}$, however, it increased with a rise in temperature. The maximum $a$-axis growth rate was $5.6 \times 10^{-2}, 8.3 \times 10^{-2}, 1.1 \times 10^{-1} \mu \mathrm{m} / \mathrm{s}$ for the first, second and third types, respectively.

\section{c) Detailed features of a plate}

The initial needle-like crystal observed in Fig. 2 grew at an angle of $75^{\circ}$ to the vertical thread; then the direction of the surface of a plate which grew on it was perpendicular to the direction of the needle, that is, at an angle of $75^{\circ}$ to the horizontal plane. In the case of the largest plate at the lower part in the figure, it took about 30 hours to grow in a supercooled cloud having a temperature gradient. Consequently a temperature difference came about between the top and the bottom of the plate. It was estimated to be $2.0^{\circ} \mathrm{C}$ from recorded data at a point and by assuming that the melting level and the needle level in the chamber are 0 and $-5^{\circ}$ respectively. This plate was sampled and observed under the optical microscope in a cold room, as shown in Fig. 6. The antisymmetric shape in the figure indicates that the $a$-axis growth rate increases with a rise in temperature in spite of a decrease in supersaturation in a supercooled cloud.

The enlargements of four representative parts, $A, B_{1}, B_{2}$ and $C$ in Fig. 6 , are shown in Figs. 7 and 8 . The following are the feature and the estimated temperature range of growth of each part:

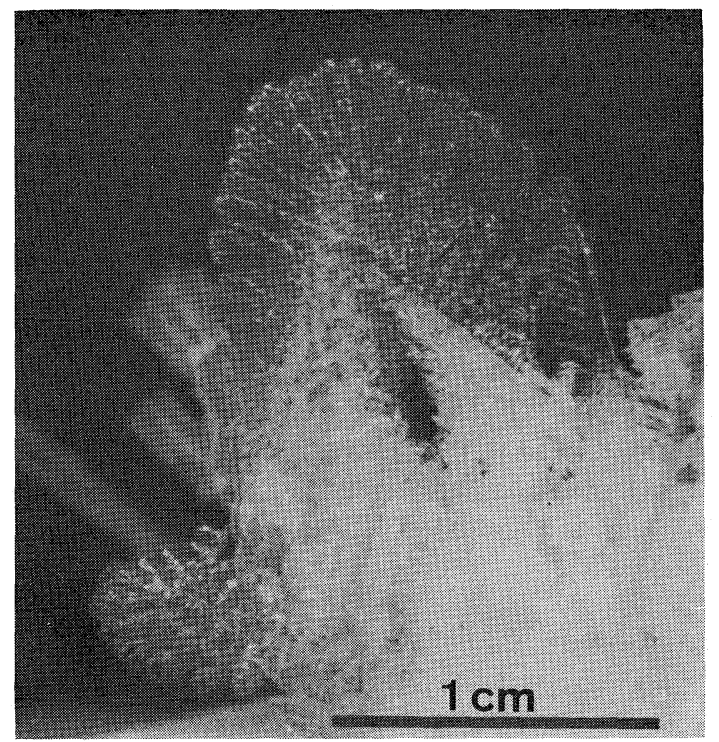

Fig. 5 Plates with a scalloped periphery grown horizontally on hard frost at $-1.5^{\circ} \mathrm{C}$.

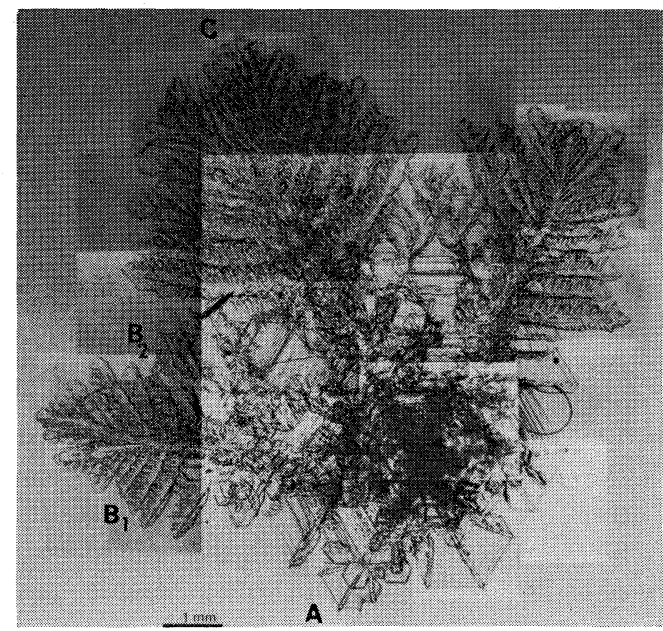

Fig. 6 The largest plate in Fig. 2.

$A$ (sector plate): This has a shape similar to the crystal in Fig. 3. That is, every branch grows parallel to an $a$-axis and prismatic faces are observable at every branch. $-4.0 \sim-3.0^{\circ} \mathrm{C}$.

$B_{1}$ and $B_{2}$ (fern-shaped plate): The two plates are composed mainly of dense parallel secondary branches. Every branch grows parallel to an $a$-axis and is arranged in order. Prismatic faces are not always observable. $-3.0 \sim-2.5^{\circ} \mathrm{C}\left(B_{1}\right)$ and $-2.5 \sim$ $-2.0^{\circ} \mathrm{C}\left(B_{2}\right)$.

$C$ (plate with a scalloped periphery): This has a highly branched round shape like a fish scale. A great difference in an appearance of branches is seen between $C$ and any of $A, B_{1}$ and $B_{2}$. That is, they do not always grow in the direction of an $a$-axis and have curved surface markings. $-2.0 \sim-1.5^{\circ} \mathrm{C}$.

A comparison of these features disclosed the following: The transition temperature at which the shape of a plate changes from a hexagonal type to a round type is about $-2{ }^{\circ} \mathrm{C}$. However, the value of $a / c$ is 50 for the large plate as a whole and changes little from part to part. The number densities of branches in parts $B_{1}$ and $C$ are 2 and 12 times that in part $A$, respectively, when every small branch or every scallop is counted as a branch. Meanwhile, observations of the cross section showed the following: The large plate is composed of many thin plates of various sizes except at the central part. This multilayered construction is especially clear at part $C$. The mean distance between adjacent two thin plates is $10 \mu \mathrm{m}$; the thickness of a thin 
plate near the pointed end is about $10 \mu \mathrm{m}$ in parts $B_{1}, B_{2}$ and $C$, and about $15 \mu \mathrm{m}$ in part $A$. (Fig. 9 shows an example of the multilayered construction of a plate with a scalloped periphery.)

\section{Discussion}

The $a$-axis growth rate of plates in the present experiment was about $1 / 2 \sim 2 / 3$ of that obtained from the free fall experiment (Yamashita, 1973 and 1974) at temperatures between -2 and $-4{ }^{\circ} \mathrm{C}$. This difference seems to show that a supercooled cloud in the former experiment is almost stationary (Yamashita and Ohno, 1984), whereas ventilation due to falling motion in a supercooled cloud in the latter might have accelerated the growth of ice crystals (Keller and Hallett, 1982).

A plate with a scalloped periphery grew in the highest temperature range in the present experiment and had no observable prismatic
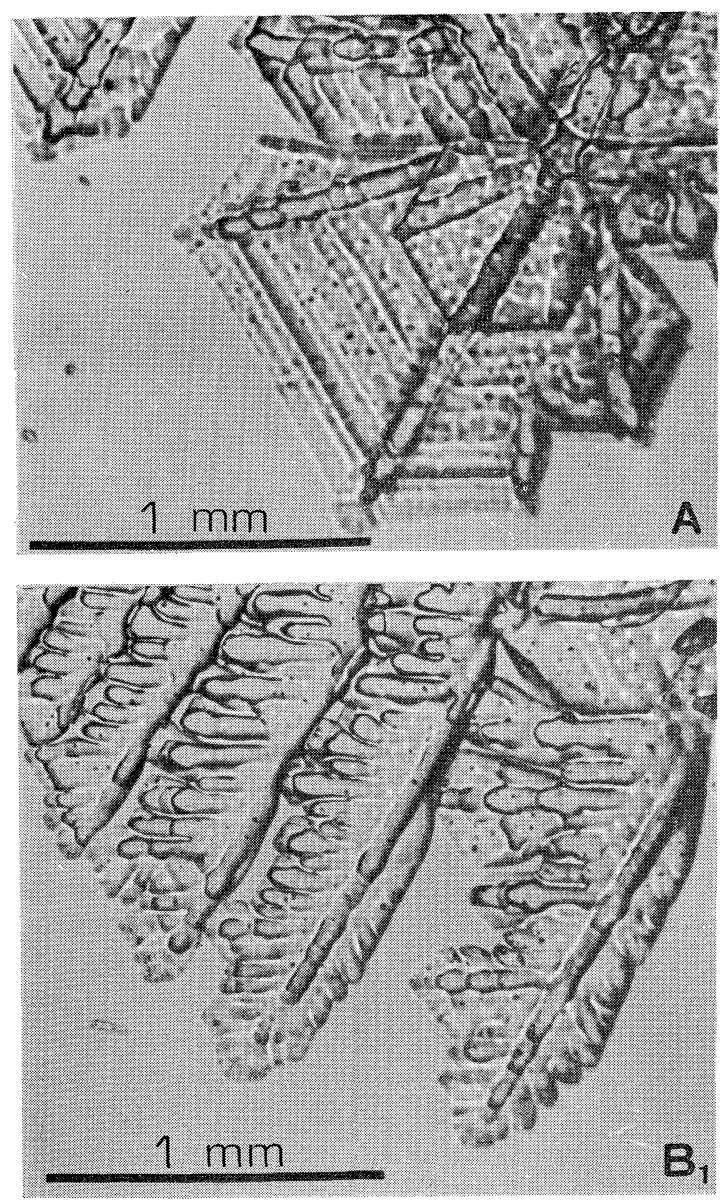

Fig. 7 Enlargements of part $A, B_{1}$ and $B_{2}$ in Fig. 6. faces. This type of plate had a highly branched shape; and every branch was not arranged in order, but was usually curved. Formation of the plate with a scalloped periphery without prismatic faces is interpreted as follows: At lower temperatures where the prismatic faces are smooth on a molecular level, i.e. singular, they grow so slowly in comparison with other highindex faces perpendicular to the $c$-axis that they largely develop themselves during the growth. On the other hand, at temperatures near the melting point, the growth rate of the prismatic face may increase to the same order as that of other high-index faces perpendicular to the $c$ axis because of surface roughening pointed out by Burton, Cabrera and Frank (1951). Therefore, the plate with a round scalloped periphery is expected to appear at temperatures not far below the melting point instead of a plate bounded by prismatic faces at lower temperatures. This change of prismatic faces and the increase in growth rate must be closely related to the quasi-liquid layer studied recently by Kuroda and Lacmann (1982).

The ice disc and the ice scallop of Keller et al. (1980) were the crystals grown at temperature region from -3 to $-8^{\circ} \mathrm{C}$ by using liquid nitrogen for nucleation. The individual

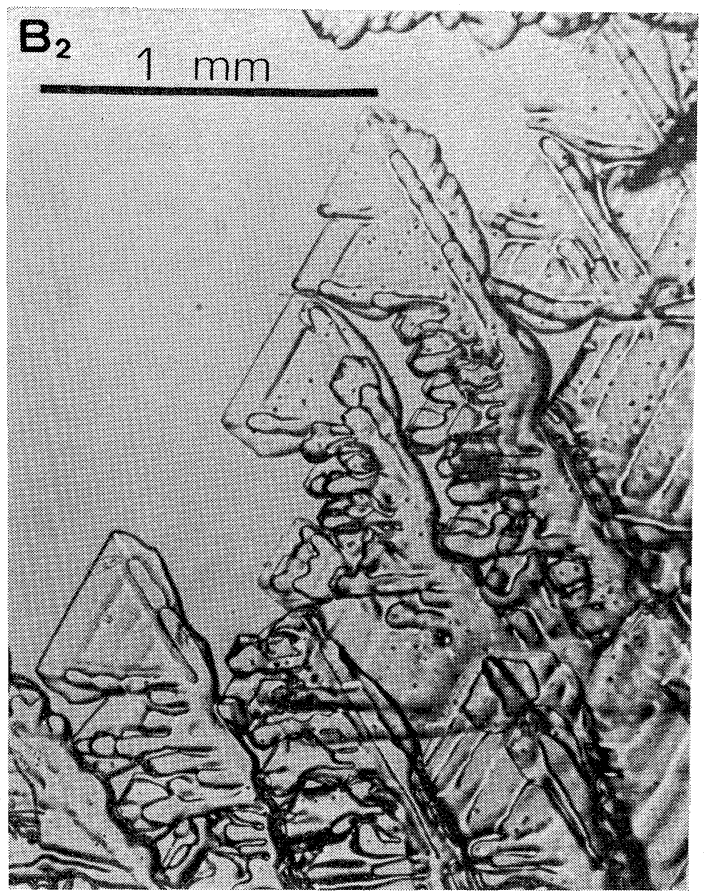




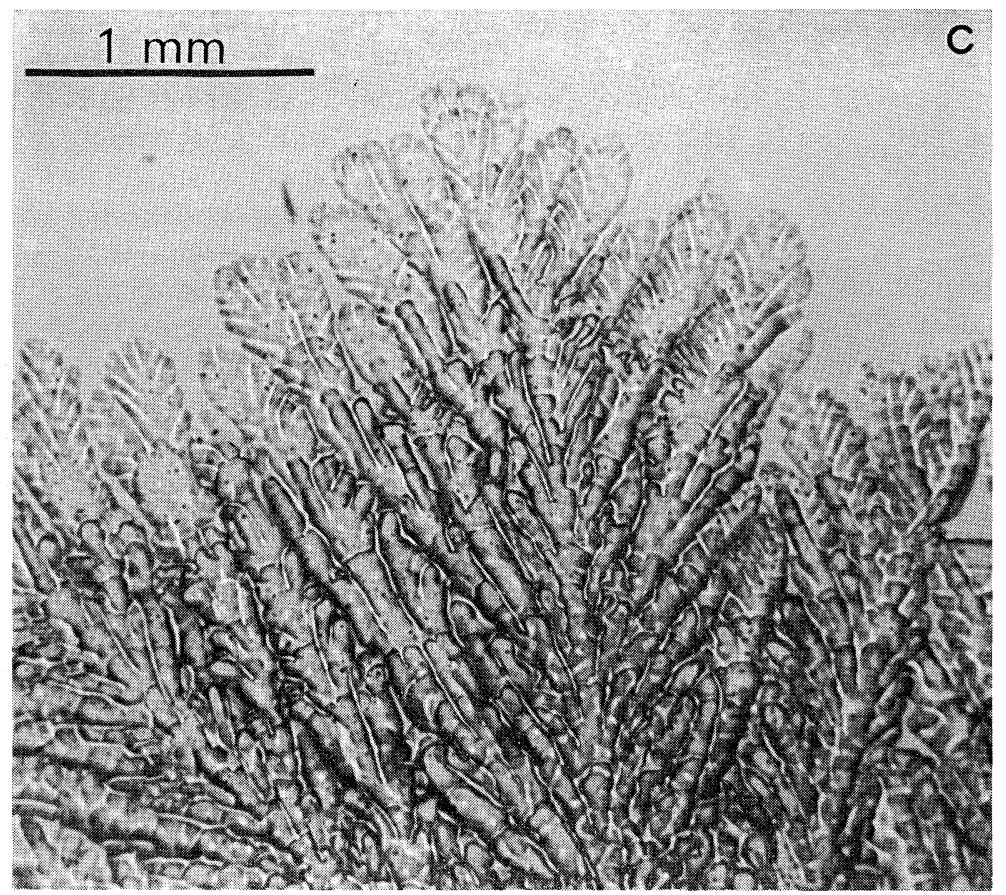

Fig. 8 Enlargement of part $C$ in Fig. 6.
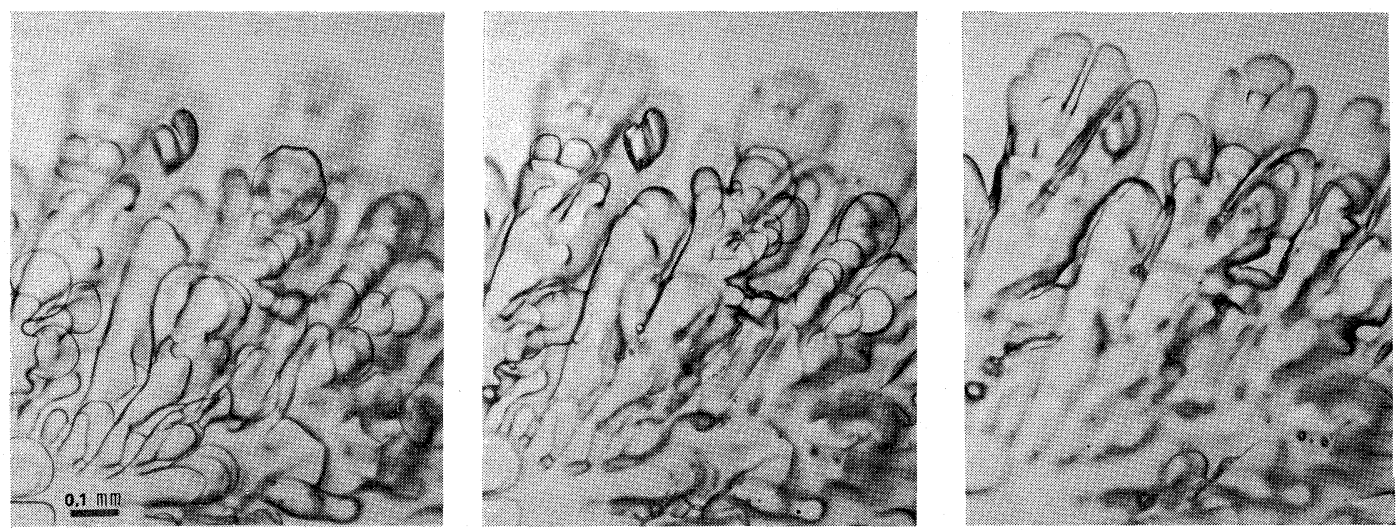

Fig. 9 Plate with a scalloped periphery grown on hard frost at $-1.5^{\circ} \mathrm{C}$, focused at three different levels. The distance between adjacent two levels: $20 \mu \mathrm{m}$.

disc and scallop are very similar to a pointed end of the plate with a scalloped periphery in the present experiment. However, they seem to be different from the plates in the present experiment judging from their growth to thick plates or columns and the difference in growing temperature. Recently Colbeck (1983) has shown that there is a transition between the highly faceted form due to kinetic growth and the rounded equilibrium form at temperatures above $-6^{\circ} \mathrm{C}$. However, the present experiment seems to be incomparable with his results because his ice crystals were grown at low supersaturations between ice plates held at different temperatures. The crevasse hoar with a scalloped periphery observed in an ice tunnel (LaChapelle, 1969) seems to be the same kind of crystal as those presented in the present work although its growth conditions have not been studied yet. It must be natural that snow discs have never been observed because their growth rate was only $1 / 10$ of that of dendritic ice crystals (Yamashita and 
Ohno, 1984) and ice crystals may not be germinated at such high temperatures.

\section{Conclusions}

Ice crystals grown in a stationary supercooled cloud at temperatures between -4 and $-1.5^{\circ} \mathrm{C}$ were monocrystalline multilayered plates grown primarily in the plane of an $a$-axis. They differed in shape (sector; fern-shaped; with a scalloped periphery) as a result of a difference in growing temperature. Their growth rates in the $a$-axis direction increased as the temperature approached the melting point despite a decrease in supersaturation in a supercooled cloud. This increase and the occurrence of a plate with a scalloped periphery at the highest temperature range from $-2 \sim-1.5^{\circ} \mathrm{C}$ were attributed to an increase in growth rate of the prism faces due to roughening that occurred at such high temperatures.

\section{Acknowledgements}

The authors are grateful to Prof. T. Kuroda of Hokkaido University and to the reviewer for valuable comments.

\section{References}

Burton, W. K., N. Cabrera and F.C. Frank, 1950: The growth of crystals and the equilibrium structure of their surfaces. Philos. Trans. R. Soc.
London Sect, A, 243, 299-358.

Colbeck, S. C., 1983: Ice crystal morphology and growth rates at low supersaturations and high temperatures. J. Appl. Phys., 54(5), 2677-2682.

Hallett, J. and B. J. Mason, 1958: The influence of temperature and supersaturation on the habit of ice crystals grown from the vapour. Proc. Roy. Soc. A, 24\%, 440-453.

Keller, V. W., C. V. McKnight and J. Hallett, 1980: Growth of ice discs from the vapor and the mechanism of habit change of ice crystals. $J$. Crystal Growth, 49, 458-464.

and J. Hallett, 1982: Influence of air velocity on the habit of ice crystal growth from the vapor. J. Crystal Growth, 69, 91-106.

Kobayashi, T., 1961: The growth of snow crystals at low supersaturation. Phil. Mag., 6, 13631370.

LaChapelle, E. R., 1969: Field Guide to Snow Crystals. J. J. Douglas Ltd.

Kuroda, T. and R. Lacmann, 1982: Growth kinetics of ice from the vapour phase and its growth forms. J. Crystal Growth, 56, 189-205.

Nakaya, U., 1954: Snow Crystals. Harvard Univ. Press.

Yamashita, A., 1973: On the trigonal growth of ice crystals. J. Meteor. Soc. Japan, 51, 307-317. , 1974: Ice crystals grown in free fall in a large cloud chamber (in Japanese). Meteorological Research Notes of Japan Meteorological Society, 123, 813-860.

- and T. Ohno, 1984: Ice crystals grown in an unforced air flow cloud chamber. $J$. Meteor. Soc. Japan, 62, 135-139.

\title{
$-4 \sim-\mathbf{1 . 5}^{\circ} \mathrm{C}$ の範囲で気相成長する氷の結晶の形態
}

\author{
山下晃・浅 野 浅 春 \\ 大阪教育大学地学教室
}

\begin{abstract}
自然循環型クラウドチェンバー内の $-4 \sim-1.5^{\circ} \mathrm{C}$ の過冷却雲の中で気相成長する氷の結晶について調べた。 -4 - $1.5^{\circ} \mathrm{C}$ の範囲で成長する結晶は全て多層構造をるった板状のものであるが， $-4.0 \sim-2.5^{\circ} \mathrm{C} て ゙ は$ 扇形, $-3.0 \sim-2.0^{\circ} \mathrm{C}$ ではシダ状, $-2.0 \sim-1.5^{\circ} \mathrm{C}$ ではスキャラップ状（又はらろこ状）を呈する。また，これら の $\mathrm{a}$ 軸方向への成長の速さは融点に近づくにつれて大きくなる。多層構造がもっとも顕著なスキャラップ状のも のではプリズム面が観察されず，多数に分岐した先端の成長の向きが必ずしも $\mathrm{a}$ 軸に平行ではないといら特徴が ある。したがって， $-2.0^{\circ} \mathrm{C}$ 以上で成長する結晶ではプリズム面の層成長が起こらないものと思われる。
\end{abstract}

